\title{
Determinant of Macro and Micro in Small Medium Enterprise Financing Through Islamic Banks
}

\author{
Roikhan Mochamad Aziz ${ }^{1}$, Tri $^{2}$ \\ UIN Syarif Hidayatullah Jakarta ${ }^{1}$, Dynivi Institute ${ }^{2}$ \\ Roikhan.ma@uinjkt.ac.id¹, Dynivity@gmail.com²
}

\begin{abstract}
The goal of this study is to explain the impact of Inflation, Indonesia Bank Sharia Certificate, Non-Performing Financing (NPF), and Third-Party Fund to Small and Medium Enterprises Financing in the sharia bank. The data used was Time Series data periods of January:2007 - July:2013. Data analysis used was Multiple Linear Regression. The results of this research show that the Inflation, Indonesia Bank Sharia Certificate, Non-Performing Financing (NPF), and Third-Party Fund, in a partial influence with Small and Medium Enterprises Financing. This is indicated by the value of Adjusted $\mathrm{R}$ Square of $99,6 \%$ while the remaining $0,4 \%$ influence by other variables. In this research note that Inflation, Non-Performing Financing (NPF), and Third-Party Fund have a significant and positive effect on the Small and Medium Enterprises Financing. Meanwhile, Indonesia Bank Sharia Certificate (SBIS) has a significantly negative effect on Small and Medium Enterprises Financing.
\end{abstract}

Keywords: Inflation, SBIS, NPF, DPK, Small, Medium Enterprises Financing

\section{Introduction}

Development in the business world or business world gave birth to many micro, small, and medium-sized businesses that are undertaken by the community. The micro, small and medium businesses which then emerged are also believed to be driving the existing economic sectors. Starting from opening employment for the community to the contribution of the MSME sector to the economy that is enough to provide fresh air. Supported by the population and social factors of the Indonesian people, the creation of MSMEs at this time is increasingly diverse. One of the special features of Micro, Small, and Medium Enterprises (MSMEs) is seen when the economic crisis of 1997-1998 shook, which weakened almost all economic sectors. At that time, SMEs were able to withstand shocks compared to large businesses.

One of the main drivers of the economy in Indonesia has so far been undeniable from the MSME sector. In this regard, there are at least some of the main functions of MSMEs in driving the Indonesian economy, namely (1) The micro and small business sector as a provider of employment for millions of people who are not accommodated in the formal sector, (2) The micro and small business sector has contributed to the formation of Gross Domestic Product (GDP), and (3) The micro sector of small and medium enterprises as a source of foreign exchange through the export of various types of products produced by this sector. (Rosa, 2019) Participation of all elements in the country is needed, both the government, the community, the business world, and financial institutions in realizing these goals. For example, the government with policies that support the development of micro, small and medium enterprises (MSMEs), people who use goods and / or services resulting from micro, small and medium enterprises (MSMEs) in meeting their needs, the business world can run healthy so that it does not occur cheating resulting in the decline of micro, small and medium 
enterprises (MSMEs), as well as financial institutions that can support and help overcome capital problems which are common problems faced by them. Limited capital will cause the space for micro, small, and medium enterprises (MSMEs) to be increasingly narrow, for example experiencing difficulties in developing their business due to being unable to fulfill orders from consumers.

The role of Micro, Small, and Medium Enterprises (MSMEs) in the Indonesian economy is very important. The national MSME sector is known to have positive characteristics such as a sector that absorbs a large workforce, accommodates the role of the poor, and is dominant in the economic structure. Based on the latest data obtained, the sector has several business actors reaching 51.3 million business units or contributing 99\%. Absorbing a workforce of

90.9 million workers or $97 \%$. Contributed GDP of IDR 2,609 trillion or $55.6 \%$. As well as making foreign exchange contributions amounting to Rp183.8 trillion or $20 \%$. In the context of fostering and developing MSMEs, the government has urged banks to increase lending to MSMEs.

In 2007 banking commitments in lending to the MSME segment increased compared to 2006, but from the 2006 credit commitments only absorbed by $80 \%$ of MSMEs. The largest composition of MSME loans is aimed at the micro-business sector for IDR 31.18 trillion, followed by small businesses IDR 27.75 trillion and medium businesses IDR 28.68 trillion (Indriyani 2007: 13). SMEs have limited access to sources of financing from formal financial institutions, especially from banks, it is known that banks are financial institutions that function as financial intermediaries between surplus units and those who lack funds (deficit unit) (Citra 2013: 5). Inflation rate movements From 2007 to 2013 can be seen to move very volatile and had reached above $10 \%$ in 2008 when the crisis that began from the subprime mortgage in the United States and has disrupted the stability of the global financial system. During the research period, it can also be seen that the inflation rate was at the lowest position in 2009 , which was $2.78 \%$.

Inflation also affects SMEs because if inflation occurs, the central bank will raise interest rates and then have an impact on raising interest rates by commercial banks, which in turn will also impact on Islamic banks so that SME interest rates go up, also because if there is inflation the business world will experience sluggishness due to demand the aggregate will go down (Chorida 2010: 5). Whereas the Sharia Bank Indonesia Certificate (SBIS) experienced fluctuations from 2007, the highest in 2011 which was Rp 9,244 billion. However, in 2007 the lowest Bank Indonesia Sharia Certificate was Rp 2,599 Billion because the bank channeled excess funds into investment in the Islamic Interbank Money Market (PUAS).

It can also be seen that the development of Non-Performing Financing (NPF) from 2007 to 2013 has increased, it may be due to the total funding provided to the public which also continues to increase. The increase in the distribution of financing in the condition of the real sector that was less conducive due to high inflation rates in the past year led to an increase in the number of problematic financing (NPF) faced by Islamic banking.

Third-Party Funds each year experienced significant growth in 2007 amounting to Rp 25,473 billion then in 2008 the number of Third Party Funds of Sharia Commercial Banks in Indonesia grew by Rp 36,852 billion, although in 2008 to 2009 there was a crisis that began with a subprime mortgage in the United States has disrupted the stability of the global financial system, but the amount of Third Party Funds at Sharia Commercial Banks Indonesia continued to increase significantly to Rp 52,271 billion, this shows that the collection of public funds at Islamic Commercial Banks was not affected by the crisis. Third- Party Funds collected continue to increase until it reaches Rp 166,453 billion in 2013. The need for these funds is needed either for investment capital or working capital and can be done in companies 
engaged in finance (financial institutions). Besides internal factors such as Third Party Funds, Assets, Revenue Sharing (NBH), Bank Indonesia Sharia Certificate, and Non-Performing Financing (NPF). The increase in macroeconomic factors such as (inflation, money supply (JUB), and conventional bank loan interest rates) indirectly affected the financing of Islamic banking. Financing from a macro point of view is one of the means of driving the real sector, as well as a means of intermediation in the banking sector channeling funds.

From the introduction, it is found that the inflation, Bank Indonesia Sharia Certificate, Non-Performing Financing (NPF), and Third-Party Funds influence the financing of Small and Medium Enterprises (SMEs). Then the problem formulation will be discussed in this study, which are:

a) How is the influence of Inflation, Bank Indonesia Sharia Certificates, Non- Performing Financing (NPF), and Partial Third Party Funds partially affecting SME Financing in Islamic banks in Indonesia?

b) How does the influence of inflation, Bank Indonesia Sharia Certificate, Non- Performing Financing (NPF), and Third-Party Funds simultaneously on SME Financing in Islamic banks in Indonesia?

The benefits to be achieved from this paper are:

a) Provides an overview of Inflation, Bank Indonesia Sharia Certificates, NPF (Non Performing Finance), Third Party Funds, on the Financing of SMEs at Islamic banks in Indonesia. As well as an increase in knowledge, learning and expansion of knowledge that is an effort to analyze an economic problem in Indonesia about the world of banking which is the largest economic activity parameter with the scope of limits analyzing the influence of inflation, Bank Indonesia Sharia Certificates, NPF and Third Party Funds on SME Financing in Islamic Banks in Indonesia.

b) It is expected to be able to broaden horizons, provide understanding and information regarding the realities of problems that occur in Indonesia to the general public, especially in the banking world, especially the Islamic banking world, in this case, namely the SME financing at Islamic banks. so that they can better understand and understand the importance of storing funds in a meeting place that is by sharia to avoid the elements that are prohibited by Allah SWT.

\section{Literature Review}

\subsection{Banks}

Banks as financial institutions that function as financial intermediaries between surplus funds and deficit units. Through banks, the excess funds can be channeled to parties who need and provide benefits for both parties. Banks accept deposits from the public (Third Party Funds) and then distribute them back in the form of credit (Dendawijaya, 2003: 25).

\section{2 .2 Micro, Small, and Medium Enterprises (MSMEs)}

By-Law Number 20 of 2008 concerning Micro, Small, and Medium Enterprises (MSMEs), which includes MSMEs are Micro Enterprises where productive businesses owned by individuals and/or individual business entities that meet the criteria for Micro Business as stipulated in the Act -In this area. Small Business is a productive economic business that stands alone, which is carried out by individuals or business entities that are not subsidiaries or 
branch companies that are owned, controlled, or become a part either directly or indirectly of medium-sized businesses or large businesses that meet the criteria Small Business as referred to in this Act. Medium Business is a productive economic business that stands alone, which is carried out by individuals or business entities that are not subsidiaries or branch companies that are owned, controlled, or become a part either directly or indirectly with a Small Business or large business with a net worth or annual sales proceeds as regulated in this Law (Purwidianti, 2014).

\section{a) Financing}

Financing is one of the main tasks of banks, namely the provision of facilities to provide funds to meet the needs of parties who constitute a unit deficit. Suhardjono (2003: 46) argues that one of the SME fund allocations can be obtained through financing based on sharia principles, whether in the form of bay ', ijārah al-muantahiyah bi al-tamlīk, syirkah and so on (Jayanti, 2016).

Inflation In general inflation means an increase in the general price level of goods/commodities and services over a certain period. According to Adiwarman Karim (2008: 135). The occurrence of inflation in the country's is caused by two factors: an increase in aggregate demand (demand-pull inflation) and an increase in production costs(cost-push inflation). While the impact of inflation on the economy of a country that is reduced investors, pushing interest rates, pushing the speculative level, economic uncertainty in the future, the competitiveness of national products is reduced, the balance of payments deficit and public welfare decreases (Wahiddudin, 2018).

\section{b) Bank Indonesia Sharia Certificates}

Based on Bank Indonesia Regulation No.10 / 11 / PBI / 2008 concerning Bank Indonesia Sharia Certificates, that the definition of SBIS is securities based on short-term sharia principles in eyes rupiah currency issued by Bank Indonesia. SBIS is issued using contracts/contracts as well. A ju'alah agreement is a promise or commitment (iltizam) to provide certain rewards ('iwadah / ju'l) for achieving results (natijah) determined from a work. Participants allowed to take part in Bank Indonesia Sharia Certificate auctions include Sharia Commercial Banks (BUS), Sharia Business Units (UUS), or brokers acting for and on behalf of BUS / UUS (Nisa \& Pancasila, nd).

\section{c) Non Performing Financing (NPF)}

According to Wiraatmadja (in M. Emier Faisal 2010: 44) what is meant by problematic financing (NPF) is financing that cannot or has the potential to be unable to return financing based on conditions that have been agreed and jointly determined suddenly without showing signs first (Shah, 2018).

\section{d) Third Party Funds}

Third party funds are deposits from the public that are deposited with Islamic banks, whose withdrawals can be made at any time without prior notice to the bank with certain withdrawal media. Funds raised from the community are the largest source of funds which are funded by banks reaching $80 \%-90 \%$. Savings funds in Islamic banks are also able to be used by banks for operational activities of Islamic banks (Wardiantika and Kusumaningtias, 2014). 


\section{e) Inflation, SBIS, NPF and DPK Relations to SME and MSME Financing}

The role of Islamic banks is currently very much needed by people who long for justice. Unlimited human needs and the need for high business capital in society, especially small and medium-sized communities, make the allocation given to small and medium-sized businesses by Islamic banking in Indonesia to be further increased (Scientific et al., 2017).

An increase in inflation will affect the implementation of SME financing, if inflation occurs will affect the repayment of installments and the level of bank profits. Bank Indonesia Sharia Certificates (SBIS) are contractive monetary policy instruments issued by Bank Indonesia. If the money in Bank Indonesia is greater than what is available in the community, this will not be beneficial for Islamic banks and customers because the funds stored in SBIS will not be used to provide productive financing so that the real sector will stagnate.

Non Performing Financing (NPF), i.e. the repayment rate of customers will affect profitability and also the performance of a bank. So the bank is endeavored to carefully select its customers to reduce the risk that will occur. Third Party Funds (DPK) are funds collected from customers that will be used for financing. This is done so that the money in the bank can spin and not be idle (idle) so that the bank will benefit and so will the customers.

\section{Methodology}

\subsection{Scope of Research}

The model in this research is the result of a merging of the theoretical framework of several banking experts who see the influence or relationship of the constructs tested in this study, namely: Inflation, SBIS, NPF and DPK on SME Financing.

\subsection{Sample Collection Method}

Data used is monthly (quantitative) numerical data in the period of January 2007 - July 2013. The author wants to know the extent to which the explanatory variables affect the response variable and by using a descriptive approach, where the authors want to describe comprehensively the state of the Banking Sharia in Indonesia, especially in terms of SME Financing.

\subsection{Data Collection Methods}

Data collection is something that must be done in the preparation of this thesis because the author in preparing the thesis requires data that is complete, accurate and can be validated. In writing this thesis, the data needed by using the following research techniques: a. Secondary data includes Indonesian banking statistics (Bank Indonesia), literature books, print media, electronic media and other reliable sources $b$. The research data was obtained through library research and field research.

\subsection{Data Analysis Methods}


In data processing, the application of the ordinary least squares method for multiple linear regression models is supported by Quantitative analysis using econometric models to get a clear picture of the relationship between the variables used in this research. The first test is a normality test were to see whether the residual value is normally distributed or not. Furthermore, the equation model obtained from data processing is attempted to not occur symptoms of multicollinearity, heteroscedasticity and autocorrelation.

To find out whether or not these symptoms will be tested first with the classic assumption test. The following are tools for testing a residual value, namely:

\section{a) Classical Assumptions Test}

1) The normality test is aimed to find out whether the variables in the study are normal or not. Normal in the sense of having a normal data distribution.

2) According to Gujarati (2006: 73), multicollinearity means that there is a perfect or definite linear relationship between some or all variables that explain (independent) of the regression model.

3) According to Gujarati (2006: 316), Heteroscedasticity occurs when the variation of Ut is not constant or often changes along with changes in the value of the independent variable.

4) According to Gujarati (2007: 112), autocorrelation aims to find out whether in a linear regression model there is a correlation between the error of disturbance in period $t$ and error in period ti (previous).

\section{b) Statistical Test}

1) The partial t-test (t-test) is used to detect how well the independent variable (Independent variable) can explain the dependent variable (Dependent variable) individually.

2) Fisher's Test (F-test) is used to find out whether the independent variable jointly influences the dependent variable (Dependent variable).

3) Coefficient of determination test is used to measure the closeness of the relationship of the model used. The coefficient of determination (R2) is a number that shows the magnitude of the ability of the variance or spread of the independent variables that explain the dependent variable or the number that indicates how much the variation of the dependent variable is influenced by the independent variables.

\section{Result and Discussion}

\subsection{History of the Development of Sharia Banks}

The history of Islamic economy, financing carried out by sharia-compliant contracts has been an important part of Muslim traditions since the time of the Prophet Muhammad. Practices such as receiving deposits, borrowing money, and sending money have been common since the time of the Prophet Muhammad.

In modern times, the first attempt to establish a bank without interest was first made in Malaysia in the mid-1940s, but this effort was not successful. However, the most successful and experimental establishment of a sharia bank innovative was established in Egypt in 1963 with the establishment of the Myt-Ghamr Bank. The success of Myt-Ghmr inspired Muslims 
around the world, so that awareness emerged that the principles of Islam could still be applied in modern business.

\subsection{Development of Islamic Banks in Indonesia}

Zainul Arifin (1999: 26) The establishment of Islamic banks in Indonesia can be traced since 1988 when the government issued the October Policy Package (Pakto) which regulates the deregulation of the banking industry in Indonesia. The scholars have tried to establish an interest-free bank, but there is no single legal instrument that can be referred to unless there is an interpretation of the existing legislation that banks can only set interest at 0 percent. After the Ulama Workshop on bank and banking interest in Bogor in August 1990, followed by the promulgation of Law No.7 / 1992 on banking in which profit-sharing banking was accommodated, then Bank Muamalat Indonesia (BMI) was established, which was the first Islamic commercial bank in Indonesia.

Then in 1998, the government adopted Law No. 10 of 1998 which regulates in detail the legal basis that can be implemented by Islamic banks, the law also provides direction for conventional banks to open Islamic branches or even convert themselves totally into Islamic banks. This opportunity was welcomed enthusiastically by the banking community. Some banks have started to open sharia divisions or branches in their institutions, some banks have fully converted themselves into sharia banks.

\subsection{Development of SME}

Financing is one of the main tasks of the bank, namely the provision of facilities to provide funds to meet the needs of parties who are deficit units (Antonio, 2012). Based on data from the Indonesian Bank of 2014, it can be seen that the highest amount of SME financing occurred in March 2013 amounting to Rp 100,793 billion and the lowest number occurred in March 2007 amounting to Rp. 15330 billion. Islamic banking in Indonesia until 2013 showed a very encouraging development, both in quality and quantity. Likewise with the existing financing in it, SME sector financing is the choice of business actors to increase their business capital. So from the above explanation, it can be concluded that the financing of the SME sector from 2007 to 2013 has increased.

\subsection{Development of Inflation}

Inflation is an economic phenomenon that is always interesting to discuss, especially regarding its broad impact on economic growth, external balance, competitiveness, interest rates, and even income distribution. Inflation also plays a role in influencing the mobilization of funds through formal financial institutions such as banking (Nurul Huda, 2008: 175).

The definition of inflation is as varied as we can find in the economic literature. This diversity of notions of inflation occurs because of the wide influence of inflation on various sectors of the economy. The close and broad relationship between inflation and various sectors of the economy gave birth to a variety of differences in our understanding and perception of inflation, as well as in formulating policies for the solution. However, in principle, there is still some unity of view that inflation is a phenomenon and an economic dilemma. Based on the 2014 Bank Indonesia data, inflation has fluctuated every month and year, for example in mid2008 due to the global economic crisis the value of inflation increased sharply above $10 \%$, and decreased again in 2009. But throughout 2009 the inflation rate was quite low or below 4\% 
and this is the lowest inflation rate since the last 20 years (source: BPS).

Inflation pressure in 2010 experienced a significant increase compared to the previous year. In September 2010 it increased to 5.8\% and in March 2011 it increased again by $6.65 \%$. The issue of limiting subsidized fuel oil and rising prices of necessities triggered inflation throughout 2010 to mid-2011. However, from September 2011 to March 2012 inflation declined and stabilized below $5 \%$. Inflationary pressures arose mainly due to disruptions in the smooth supply of foodstuffs which were heavily affected by weather anomalies.

\subsection{Development of Bank Indonesia Sharia Certificates}

Bank Indonesia Sharia Certificates are certificates issued by Bank Indonesia as proof of short-term fund deposits. Bank Indonesia Sharia Certificates is a monetary instrument by sharia principles at Islamic Banks was created in the context of implementing monetary controls. Bank Indonesia issues monetary instruments based on sharia principles and can be utilized by Islamic banks to overcome excess liquidity.

Based on the 2014 Bank Indonesia data, Bank Indonesia Sharia Certificates experienced fluctuations from March 2007 - March 2013. This is because Islamic banking third party funds also tend to fluctuate so that the absorption of third party funds placed by SBIS has also decreased. In this period, the lowest Bank Indonesia Sharia Certificates occurred in September 2008, amounting to 413 billion, then moved back up to March 2013 amounting to 5,611 billion due to the increase in third party funds where customers have a high level of trust to place their funds in Islamic banks. Then in September 2012, there was a decrease at the level of 3,412 billion, this is because Islamic Bank DPK tends to be used for financing in the real sector. And until March 2013 Bank Indonesia Sharia Certificates has increased again because the addition of third party funds has always gone up from year to year.

\subsection{Development of Non Performing Financing (NPF)}

NPF or commonly called Non Performing Loans in high conventional banks results in the non-functioning of the bank intermediation function optimally because it decreases the circulation of bank funds thereby reducing the opportunity for banks to earn income. The NPF also forces banks to form several reserves to maintain bank liquidity and solvency to protect depositors. The greater the NPF, the greater the opportunity cost to be borne by the bank. Therefore, NPF should be as low as possible (Hasanudin \& Prihatiningsih, 2010: 27).

Based on the 2014 Bank Indonesia data, it shows that the level of NPF tends to increase and decrease (fluctuating). In March 2013 the level of NPF at Islamic banks was 4,434 billion, the level of NPF this month was the highest throughout 2013. The level of NPF at the Islamic banks from 2007 to 2013 was above the normal limits of Islamic banking NPF which is 5\%. The lowest level of problem financing for Islamic banks was in March 2007, amounting to 1,194 billion. NPF Islamic banks in Indonesia experienced significant fluctuations. The level of NPF is above the standard set by Bank Indonesia of 5\%. In other words, the level of problem financing in Islamic banks is still not well controlled.

\subsection{Development of Third Party Funds}

Third Party Funds are funds obtained from the public, both individuals and business entities, obtained by banks using various deposit product instruments owned by banks. In some banks, these public funds are generally the largest funds owned, this is by the bank's 
function as collecting funds from the public. And an increase in third party funds collected by banks from the public will usually be followed by an increase in the total amount of financing provided to the public.

Third party funds are the most important component of funds, the amount of profit (profit) that will be generated will depend on how much the bank's ability to collect deposits and then distribute financing or make investments that can increase value and assets. Based on Bank Indonesia data in 2014, it shows that DPK from March 2007 - March 2013 has increased, in March 2007 the amount of DPK was Rp. 21,883 billion and in March 2013 DPK increased to Rp. 156,964 billion. This increase in third party funds is a direct impact of the development of office networks and a range of banking services and a high enough level of public trust to deposit funds in Islamic Banks. This can be seen from the graph that continues to increase.

\subsection{Results and Data Analysis}

\subsubsection{Classical Assumption Test}

\section{a) Normality Test}

The normality test is done in two ways, namely the histogram and the Jarque-Bera (JB) test. To see whether the data is normally distributed or not is to look at the JB coefficient and its probability. If the JB value is not significant (less than 2) then the data is normally distributed. Meanwhile, if the probability is greater than $5 \%$, then the data is normally distributed. Using the Normality Test in this study shows that the probability of JBstat = $0.837857>0.05$, then Ho is accepted and $\mathrm{Ha}$ is rejected, meaning that the data is normally distributed.

\section{b) Multicollinearity Test}

Table 1. Correlation Matrix Table

\begin{tabular}{ccccc}
\hline & INF & LNSBIS & LNNPF & LNDPK \\
\hline INF & 1.000000 & -0.474965 & -0.388646 & -0.367017 \\
LNSBIS & -0.474965 & 1.000000 & 0.523671 & 0.637483 \\
LNNPF & -0.388646 & 0.523671 & 1.000000 & 0.948042 \\
LNDPK & -0.367017 & 0.637483 & 0.948042 & 1.000000 \\
\hline
\end{tabular}

From the table, the multicollinearity test analysis with the correlation matrix above shows that the correlation coefficient is above 0.8 , so there is a multicollinearity problem.

\section{c) Heteroscedasticity Test}

Table 2. Heterocedasticity Test Heteroskedasticity Test: White

\begin{tabular}{cccc}
\hline F-statistic & 1.611472 & Prob. F(13,65) & 0.1048 \\
Obs*R-squared & 19.25537 & Prob. Chi-Square(13) & 0.1154 \\
Scaled explained SS & 14.80587 & Prob. Chi-Square(13) & 0.3196 \\
\hline
\end{tabular}

From the table above table note that the value of OBS * R2 is 19.25537 and the probability of Chi-Square is 0.1154 which is greater than the $\alpha$ value of 0.05 . Because the Chi-square probability value $>5 \%$, in this case, Ho is accepted so that it can be concluded that the data is 
homoscedastic after the White Test.

\section{d) Autocorrelation}

Table 3. Test The Breusch-GodfreyTest Breusch-Godfrey Serial

Correlation LM Test:

\begin{tabular}{cccc}
\hline F-statistic & 3.488613 & Prob. F(54,20) & 0.0016 \\
Obs*R-squared & 71.41788 & Prob. Chi-Square(54) & 0.0563 \\
\hline
\end{tabular}

DWis between 1.54 to 2.46 so the model does not have an auto operation. From the output estimation table, Durbin Watson obtained 2.105525. Table 3 shows the results of the R-square observations on the Brefch Godfrey serial correlation LM test of $0.0563>0.05$ so that this test was declared to be free of autocorrelation.

\subsubsection{Statistical Test}

a) Partial Test (Statistical Test t)

Table 4. Test Table $\mathrm{t}$

\begin{tabular}{ccccc}
\hline Variable & Coefficient & Std. Error & t-Statistic & Prob. \\
\hline C & 0.915211 & 0.542133 & 1.688168 & 0.0956 \\
INF & 0.004808 & 0.002221 & 2.164449 & 0.0337 \\
LNSBIS & -0.043499 & 0.010697 & -4.066388 & 0.0001 \\
LNNPF & 0.111505 & 0.037369 & 2.983867 & 0.0039 \\
LNDPK & 0.898181 & 0.024606 & 36.50247 & 0.0000 \\
\hline
\end{tabular}

The probability value of the Inflation, SBIS, NPF, and DPK variables is smaller than $\alpha=$ $5 \%$, then $\mathrm{H} \mathscr{C}$ is accepted. So it can be said that the Inflation, SBIS, NPF, and DPK variables have a significant effect on SME financing in Islamic banks in Indonesia in the January 2007July 2013 period.

a) Simultaneous Test (F Test) To test whether the independent variables simultaneously influence variables bound, the F-test is used by looking at the probability value of the Fstatistics. Regression results obtained from the F-statistic probability value of 0.000000 , which means less than $\alpha=5 \%$. The hypothesis is as follows: Ha: Allegedly there is an influence of inflation, Bank Indonesia Sharia Certificate, Non Performing Financing (NPF) and third party funds on SME financing in Islamic banks in Indonesia simultaneously. Seeing the probability value of the F-statistic less than $\alpha=5 \%$, then $\mathrm{Ha}$ is accepted and it can be concluded that the inflation, Bank Indonesia Sharia Certificate, Non Performing Financing (NPF) and Third-party funds have a significant simultaneous effect on SME financing in Islamic banks in Indonesia.

b) The coefficient of determination aims to see how much the ability of the independent variables to explain the dependent variable. Based on the results of data processing, the coefficient of determination is 0.996099 . It means: The ability of inflation, Bank Indonesia Sharia Certificates, Non Performing Financing (NPF), and Third Party Funds in explaining SME financing variables in Islamic banks in Indonesia are of $99.6 \%$ while the remaining $0.4 \%$ is explained by other factors not examined in this study. 


\section{Conclusion}

Based on the results above, the following conclusions are explained below:

a) Simultaneously Inflation variables, Bank Indonesia Sharia Certificates Non Performing Financing (NPF) and Third Party Funds have a significant effect on SME financing of Islamic banks in Indonesia.

b) Partially, the inflation variable has a significant positive effect on SME financing in Islamic banks in Indonesia. This is because rising inflation causes the prices of goods in a country to increase. So that people reduce their consumption levels and are more inclined to save and invest when people save a lot, the funds collected in the Bank will be channeled into SME financing.

c) Partially, the variable Bank Indonesia Sharia Certificate has a significant negative effect on SME financing in Islamic banks in Indonesia. This is because in terms of excess liquidity, Islamic banks will buy SBIS and what happens will reduce the SME financing side, SME financing will decline, the real sector will be stalled because bank funds have been used to buy SBIS.

d) Partially the Non Performing Financing (NPF) variable has a significant positive effect on SME financing in Islamic banks in Indonesia.. This is because the market share of Islamic banking is still low when compared to the conventional banking market share. Then most customers are customers who are loyal to Islamic banking.

e) Partially, the Third Party Fund (DPK) variable has a significant positive effect on SME financing in Islamic banks in Indonesia.. This is because, with the increase in third party funds collected, there will also be an increase in funding or channeling of funds to be provided by Islamic banks to the public.

\section{References}

[1] Anugrah, Rizki Tri, dkk. Pemberdayaan Usaha Mikro, Kecil dan Menengah (UMKM) melalui Pembiayaan dengan Prinsip Bagi hasil oleh Lembaga Keuangan Syariah, Fakultas Hukum, Universitas Brawijaya Malang, (2011).

[2]. Ambarwati, Septiana. Faktor-faktor yang mempengaruhi Pembiayaan Murabahah dan Mudharabah pada Bank Umum Syariah di Indonesia, UI, Program Studi Timur Tengah, (Juli 2008).

[3]. Antonio, Muhammad Syafi'i. Bank Syariah: Dari Teori ke Praktik, Cetakan pertama, Gema Insani, Jakarta, (2001).

[4]. Arianti, Wuri dan Muharam, Harjum. Analisis Pengaruh Dana Pihak Ketiga (DPK), Capital Adequacy Ratio (CAR), Non Performing Financing (NPF), dan Return Of Asset (ROA) terhadap Pembiayaan Pada Perbankan Syariah, Universitas Diponogoro, (2011).

[5]. Ilmiah, J., Infak, K., \& Hasanah, N. Pengaruh Tingkat Suku Bunga, Inflasi dan Rasio Kecukupan Modal terhadap Penyaluran Kredit UMKM oleh Bank Umum di Indonesia Tahun 2007 - 2013. (2017).

[6]. Jayanti, S. D. Pengaruh Inflasi dan BI Rate Terhadap Pembiayaan Usaha Mikro Kecil dan Menengah (Studi Kasus Pada Bank Umum Syariah). 2(2), 86-105. (2016).

[7]. Nisa, C., \& Pancasila, U. (n.d.). Analisis dampak kebijakan penyaluran kredit kepada umkm terhadap pertumbuhan pembiayaan umkm oleh perbankan. 11(2).

[8]. Rosa, Y. Del. Pengaruh Inflasi Dan Suku Bunga Terhadap Omset Umkm Kota Padang. V(3), 133-145. (2019).

[9]. Syah, T. A. Pengaruh inflasi, bi rate, npf, dan bopo terhadap profitabilitas bank umum syariah di 
indonesia. 6(1), 133-153. (2018).

[10]. Wahiddudin, M. Pengaruh Inflasi, Non Performing Finacing (NPF) Dan BI Rate Terhadap Pembiayaan Usaha Mikro Kecil Dan Menengah (UMKM) Pada Bank Umum Syariah 2012-2017. Al Amwal, 1(1), 76-89. (2018).

[11]. Rodoni, Ahmad, Panduan Penulisan Skripsi, FEIS UIN Press, Jakarta, 2010.

[12]. Roesmana, Duddy., Nurul Chotimah. Variabel-variabel Yang Mempengaruhi Pembiayaan Pada Perbankan Syariah Di Indonesia Ditinjau Dari Sisi Penawaran, vol.2, No.2, (Juni 2008).

[13]. Saeed, Abdullah. Bank Islam dan Bunga, Pustaka Pelajar, (2008).

[14]. Santoso, Singgih. Statistik Parametrik: Konsep dan Aplikasi dengan SPSS, PT Elex Media Komputindo, Jakarta, (2010).

[15]. Sudarsono, Heri. Bank dan Lembaga Keuangan Syariah Deskripsi dan Ilustrasi, Ekonisia, Yogyakarta, (2008).

[16]. Suhrawardi K. Lubis. Hukum Ekonomi Islam. Jakarta: Sinar Grafika, (2004).

[17]. Sukirno, Sudono. Makro Ekonomi: Teori Pengantar, Raja Grafindo Persada, Jakarta, (2004).

[18]. Sumarti. Analisis Kinerja Keuangan pada Bank Syariah Mandiri di Jakarta, FE Universitas Muhammadiyah Surakarta, (2007).

[19]. Winarno, W Wahyu.Ekonometrika dan Statistik dengan Eviews, Edisi 3, Yogyakarta: Sekolah Tinggi Ilmu Managemen YKPN, (2009). 